\title{
Wpływ technologiczności na awarię spawanej konstrukcji aluminiowej
}

\section{Producibility aspects influence on aluminum welded roof failure}

\section{Streszczenie}

W artykule omówiono zależność pomiędzy awarią spawanej konstrukcji zadaszenia a jakością złączy spawanych. Na niezawodność konstrukcji ma wpływ nie tylko jakość złączy, ale i ich konstrukcja. Artykuł dotyczy złączy wykonanych na elementach nośnych zadaszenia obiektu widowiskowego. Podczas obciążenia wywołanego silnym wiatrem konstrukcja dźwigarów zadaszenia uległa uszkodzeniu. W celu zbadania przyczyny awarii, uszkodzone złącza poddano badaniom laboratoryjnym $\mathrm{i}$ analizie technologiczności. Badania wykazały wiele niedociągnięć zarówno w zakresie samej technologii wykonania, jak i błędów konstrukcyjnych.

\section{Wstęp}

Współczesne rozwiązania wymagają stosowania nowych lekkich i odpornych na korozję materiałów konstrukcyjnych. Na szczególną uwagę zasługują stopy aluminium, które należy do metali o największej koncentracji w skorupie ziemskiej. Do najczęściej wytwarzanych konstrukcji aluminiowych należą [1, 13]: estrady stacjonarne, estrady mobilne, zadaszenia budynków, elewacje budynków, lekkie pawilony (szkło i aluminium), budowle futurystyczne, kładki, balustrady, wiaty, schody, pomosty, zbiorniki, jachty, łodzie i obiekty pływające marynarki wojennej.

Rozpowszechnienie spawanych konstrukcji aluminiowych sprawia, że po stali materiał ten zajmuje drugą pozycję jako materiał konstrukcyjny. $Z$ doświadczeń w zakresie wytwarzania wynika, że jest to materiał trudny do spawania. Spawanie konstrukcji ze stopów aluminium, mimo że jest dość szeroko stosowane,

Dr inż. Jan Stabryła, dr inż. Krzysztof Dutka - Uniwersytet Warmińsko-Mazurski w Olsztynie. ciągle stwarza wiele problemów technologicznych. Już sam dobór materiału rodzimego do warunków eksploatacji wymaga szczegółowej analizy oddziaływania czynników mechanicznych i chemicznych na konstrukcję zarówno w fazie wytwarzania, jak i eksploatacji. Jurczak zaleca, aby w warunkach oddziaływania korozji naprężeniowej stosować stop AIZn5Mg2CrZr [2]. Złącza należy wykonywać metodą spawania łukowego w osłonie gazu obojętnego przy użyciu drutu SAIMg$5 Z n 2 Z r 0,4$. Na jakość złączy ma istotny wpływ nie tylko szczelna osłona gazu obojętnego, ale i przygotowanie brzegów materiału do spawania. Konstrukcje aluminiowe, ze względu na znaczną plastyczność materiału, w celu zabezpieczenia stabilności powinny być usztywniane żebrami, na co zwraca uwagę w swojej publikacji Hulimka [1]. Trudności w uzyskaniu prawidłowego wtopienia wynikają ze skłonności aluminium do utleniania. Już w ciągu kilku minut aluminium pokrywa się cienką warstwą tlenku - nawet w temperaturze otoczenia. Intensywność utlenienia rośnie ze wzrostem temperatury. Podatność aluminium na utlenianie prowadzi do powstawania niezgodności spawalniczych typu przyklejenie, gdyż na brzegach spawanego złącza przy dostępie tlenu powstaje warstwa $\mathrm{Al}_{2} \mathrm{O}_{3}$ o temperaturze 
topnienia powyżej $2000^{\circ} \mathrm{C}$, tj. trzykrotnie wyższej od temperatury topnienia aluminium. Jest to obok pęknięcia jedna z najgroźniejszych niezgodności, gdyż nie jest widoczna, a skutkuje gwałtownym pękaniem złącza przy obciążeniu. Stąd bardzo ważne jest zarówno dokładne oczyszczenie brzegów łączonych elementów przed spawaniem, jak i utrzymywanie szczelnej osłony gazowej spoiny podczas spawania. Często popełnianym błędem jest pomijanie osłony grani obojętnym gazem formującym. Drugim istotnym czynnikiem decydującym o jakości złącza jest jego kształt. Wiele prac przytacza zalecenia konstrukcyjne dotyczące prawidłowego rozwiązania konstrukcyjnego zapewniającego wytworzenie konstrukcji wolnej od wad typu pęknięcie,

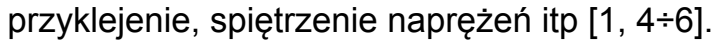

Ogólnie wszystkie wymagania co do poprawności kształtu złączy zostały zdefiniowane jako technologiczność konstrukcji.

Pod pojęciem technologiczności konstrukcji przyjęto rozumieć szereg cech spełniających postulaty funkcjonalności oraz wymagania dotyczące jej wykonania: łatwość, niski koszt, odpowiednie materiały, a także użytkowania: niezawodność, trwałość, podatność na naprawy i końcowy cykl eksploatacji podatny na recykling. Poprawna pod względem technologiczności jest konstrukcja, której kształt nie sprzyja powstawaniu wad - niezgodności spawalniczych.

Zarówno błędy technologiczne, jak i konstrukcyjne są obok braku nadzoru spawalniczego przyczyną większości awarii i katastrof budowlanych [1, 5, 7]. Większości tych zdarzeń można uniknąć, stosując zalecenia norm przedmiotowych $[8 \div 13]$ i wytyczne dotyczące technologiczności konstrukcji spawanych [6].

\section{Cel, przedmiot i zakres badań}

Przedmiotem badań były elementy łączników kratowych uszkodzone w wyniku awarii konstrukcji estradowej. Widok konstrukcji zadaszenia po awarii powstałej w wyniku burzy przedstawiono na rysunku 1 . Silny wiatr

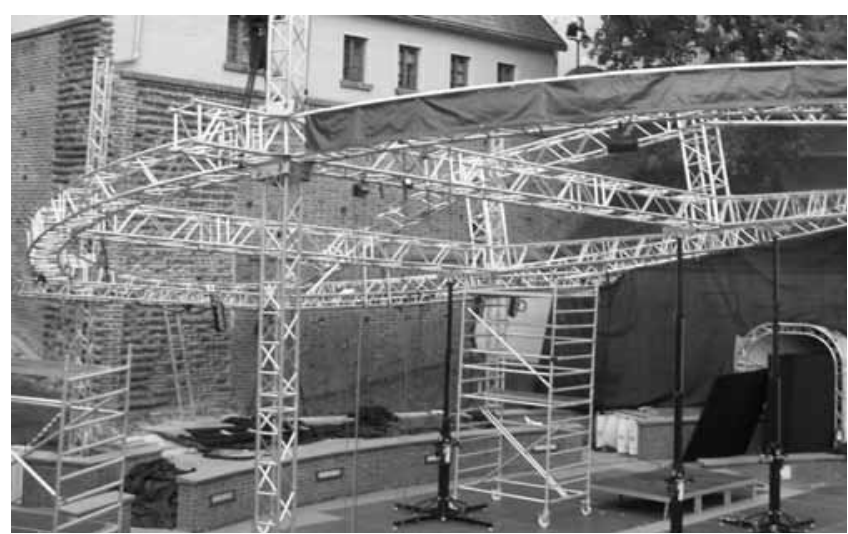

Rys. 1. Widok ogólny uszkodzonej konstrukcji

Fig. 1. Damaged structure view

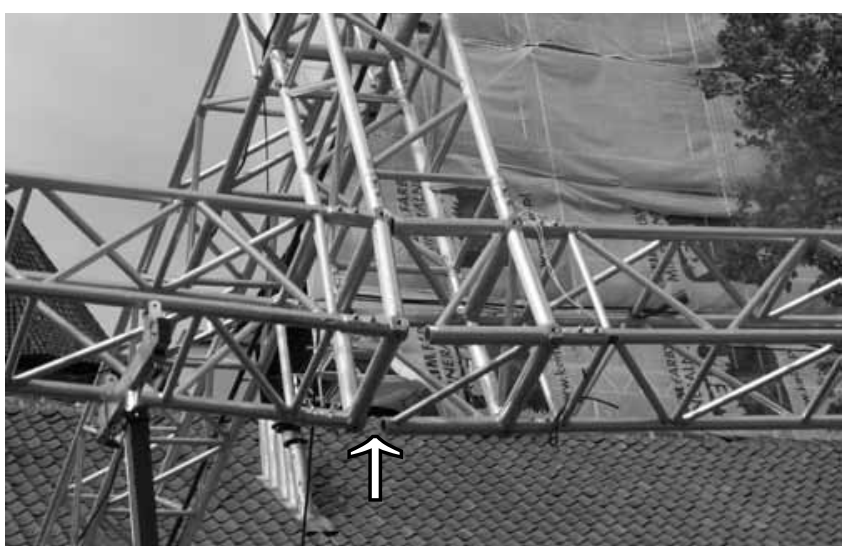

Rys. 2. Uszkodzony łącznik dźwigara tyınego

Fig. 2. Damage roof back beam connector

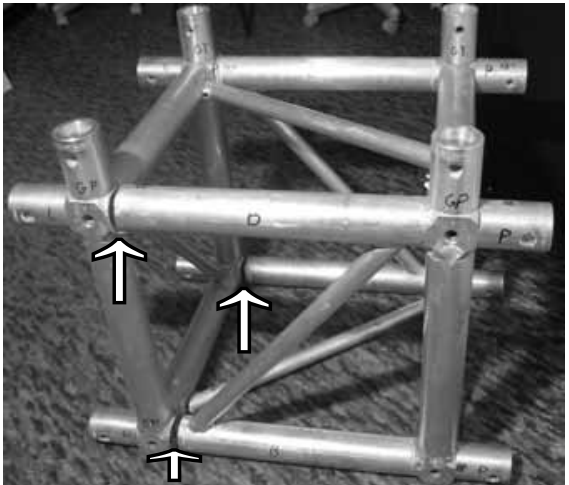

Rys. 3. Łącznik dźwigara tylnego (B). Widoczne uszkodzenia złączy spawanych strony lewej. Obustronne oderwanie spoin krzyżulca górnego i lewej strony krzyżulca dolnego

Fig. 3. Roof back beam connector (B). Left side welded joint failure. Double-sided weld fracture in upper cross brace and on the left side of bottom cross brace

działający na brezentowe pokrycie konstrukcji spowodował dynamiczne obciążenia, w wyniku których awarii uległy dwa łączniki dźwigarów poziomych i pionowych. Podczas oględzin wstępnych stwierdzono pęknięcia złączy spawanych. Uszkodzenia łącznika tylnego dźwigara poziomego przedstawiono na rysunku 2. Uszkodzone łączniki zostały wymontowane i przekazane do badań laboratoryjnych. Na rysunku 3 widoczny jest jeden z elementów dostarczonych do badań.

\section{Analiza konstrukcji łączników kratowych}

Konstrukcja łącznika ze stopu aluminium (AIMgSi1 F31) ma kształt sześcianu o wymiarach $510 \times 510 \times 510 \mathrm{~mm}$. Krawędzie łącznika wykonane są z rur ø60x5 mm złączone w narożach prostopadłościennymi kostkami o boku $60 \mathrm{~mm}$. Boki ścian usztywnione są krzyżulcami rurowymi ø30x3 mm. Szkielet konstrukcji wykonany został metodą spawania. Do prostopadłościanów stanowiących węzły narożne ściany lewej, prawej i górnej przymocowane są końcówki złączne o średnicy zewnętrznej $59 \mathrm{~mm}$ i długości $85 \mathrm{~mm}$ za pomocą stalowych ocynkowanych śrub montażowych 
M16 klasy 8.8. Pobrane do badania łączniki kratowe oznaczono jako A - z dźwigara przedniego i B - dźwigara tylnego. Celem identyfikacji poszczególne uszkodzone złącza oznaczono literowo. Przykład oznaczenia: ADPL - łącznik przedni, pas dolny, ściana przednia strona lewa.

W obydwu łącznikach stwierdzono całkowite zniszczenie złączy spawanych strony lewej. Lewa ściana obydwu łączników została całkowicie oddzielona od reszty konstrukcji. Ponadto w łączniku B wystąpiło całkowite oddzielenie krzyżulca górnego od konstrukcji.

Pękanie nastąpiło od spoin węzłów dolnych strony lewej. Elementy rurowe nie noszą śladów odkształceń plastycznych. Pęknięciu uległy złącza spawane bez naruszenia ciągłości materiału rodzimego. Dodatkowo zaobserwowano częściowe pęknięcia węzłów w płaszczyźnie poziomej pomiędzy kostką a rurą pionową oraz obydwu górnych złączy łącznika A strony lewej - w podobny sposób jak w łączniku $B$.

\section{Badania wizualne uszkodzonych elementów konstrukcji}

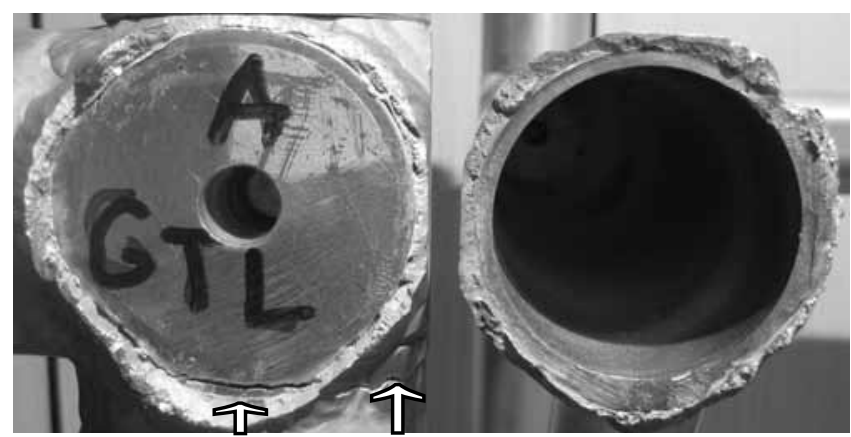

Rys. 4. Pęknięta spoina łącznika A (węzeł górny, tylny lewa strona). Dodatkowo widoczne pęknięcie spoiny prostopadłe do płaszczyzny rysunku - oznaczone strzałkami

Fig. 4. Crack in the weld in A connector (upper truss joints, on the back left side). Moreover, the crack in the joint perpendicular to the viewing side - marked by arrows

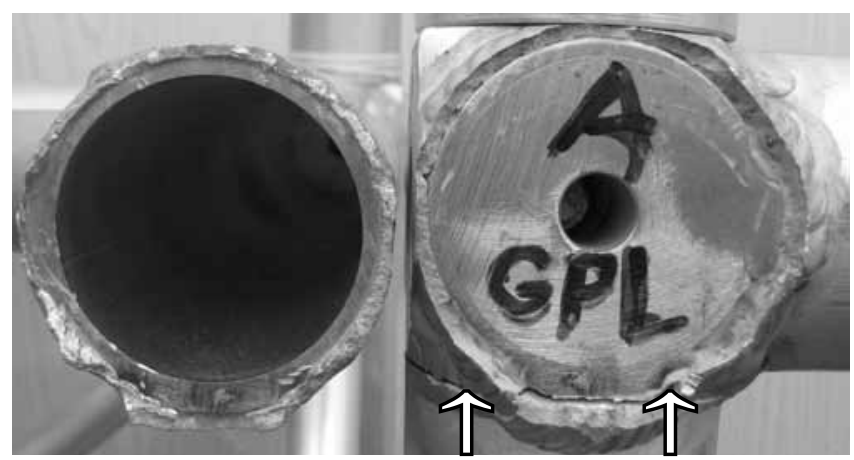

Rys. 5. Pęknięta spoina łącznika A (węzeł górny, przedni, lewa strona). Dodatkowo widoczne pęknięcie spoiny prostopadłe do płaszczyzny rysunku - oznaczone strzałkami

Fig. 5. Crack in the weld in A connector (upper truss joints, on the front left side). Moreover, the crack in the joint perpendicular to the viewing side - marked by arrows

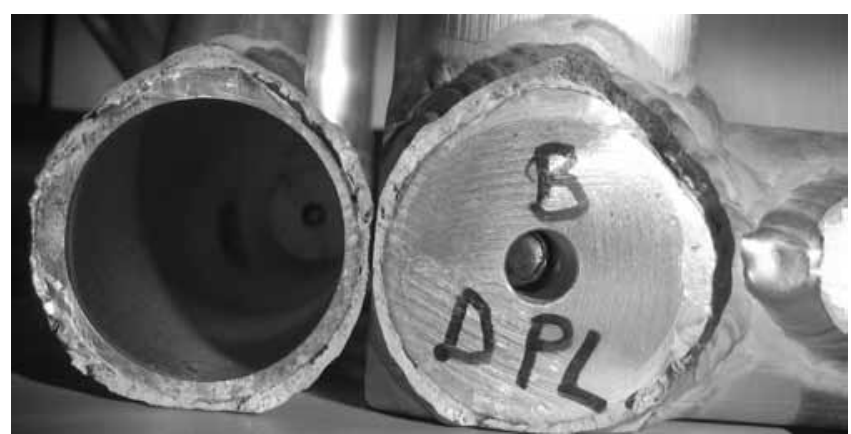

Rys. 6. Pęknięta spoina łącznika B (węzeł dolny przedni, lewa strona)

Fig. 6. Crack in the weld in B connector (bottom truss joints, on the front left side).

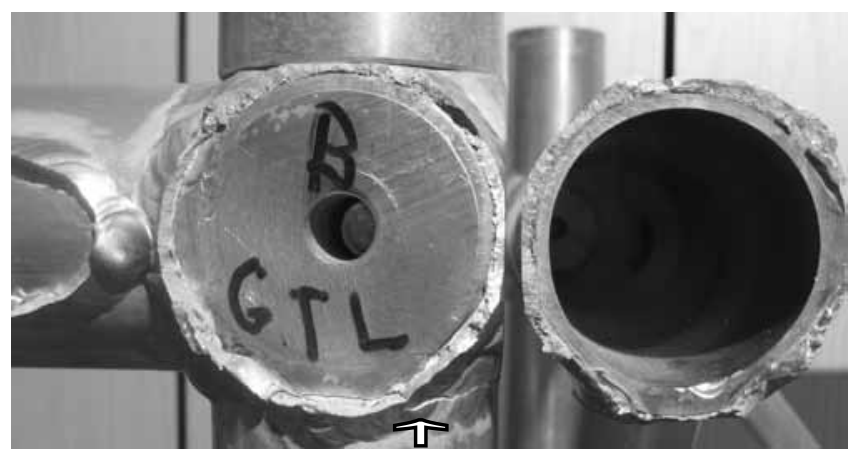

Rys. 7. Pęknięta spoina łącznika B (węzeł górny tylny, lewa strona). Dodatkowo widoczne pęknięcie spoiny prostopadłe do płaszczyzny rysunku - oznaczone strzałką

Fig. 7. Crack in the weld in B connector (upper truss joints, on the back left side). Moreover, the crack in the joint perpendicular to the viewing side - marked by arrows

Przykładowy widok pękniętych złączy w kierunku na rurę i w kierunku na kostkę węzła przedstawiono na rysunkach $4 \div 7$.

Wygląd pękniętych spoin jest podobny, co wskazuje na stosowanie jednakowej technologii spawania, w tym sposób przygotowania elementów do spawania. Czoła łączonych do prostopadłościanów rur były zestawiane na styk bez ukosowania. Charakter przełomu przebiegającego w każdym przypadku przez spoinę jest kruchy, bez widocznych stref odkształcenia plastycznego. Pękanie przebiegało wzdłuż płaszczyzny styku rur z kostkami w węzłach. Widoczna na rysunkach $4 \div 7$ powierzchnia czołowa rur we wszystkich przypadkach jest przetopiona na głębokość $2 \div 2,5 \mathrm{~mm}$, a ok. $20 \%$ długości każdej spoiny obwodowej wykazuje prawie całkowity brak przetopu. Oznacza to, że cały przekrój czołowy rury nie został przetopiony, a ciągłość spoiny zapewnia wypukłość nadlewu lica spoiny. Na każdym obwodzie są to obszary w strefie ścian łącznika. W takiej sytuacji jedynie nadlew lica był przekrojem, który przenosił obciążenia. Dodatkowo na części obwodu nadlewy spoin były zeszlifowane na płaszczyznach zewnętrznych kostek węzłowych (rys. 4 i 7), aby umożliwić dobre przyleganie elementów łączonych za pomocą śrub, co dodatkowe zmniejszyło przekrój nośny złączy. Takie wykonanie złącza spowodowało, że jego nośność została obniżona o ok. $80 \%$, co jest widoczne na schemacie (rys. 8). 

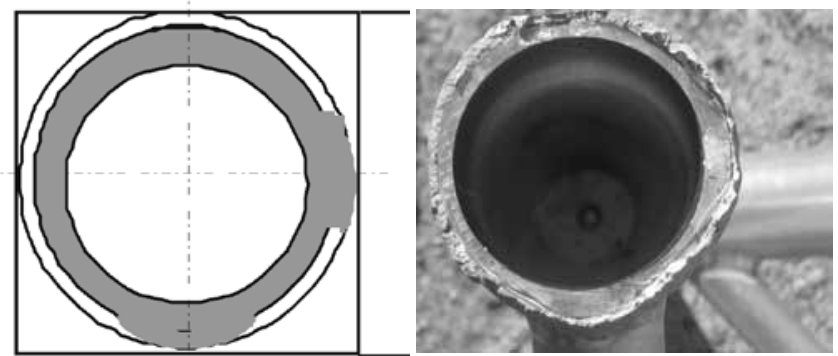

Rys. 8. Oszacowanie nośnej powierzchni złącza. Szarym kolorem zaznaczono braki przetopu występujące we wszystkich złączach, które uległy zniszczeniu

Fig. 8. Carrying joint surface estimation. Lack of joint penetration observed in all failure joints marked gray

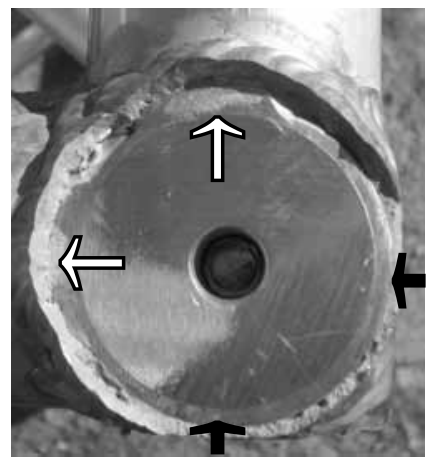

Rys. 9. Zeszlifowane nadlewy spoin wychodzące ponad płaszczyznę kostki węzłowej oznaczono strzałkami czarnymi, a strefy pełnego braku przetopu strzałkami białymi

Fig. 9. Excess weld metal over the truss joint after grinding - black arrows, and lack of joint penetration zones - white arrows

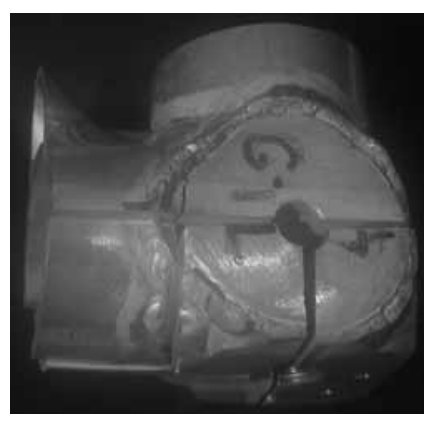

Rys. 10. Pocięty węzeł łącznika przedniego (AGTL)

Fig. 10. The truss joints (bend cube) in the front connector after cutting (AGTL)
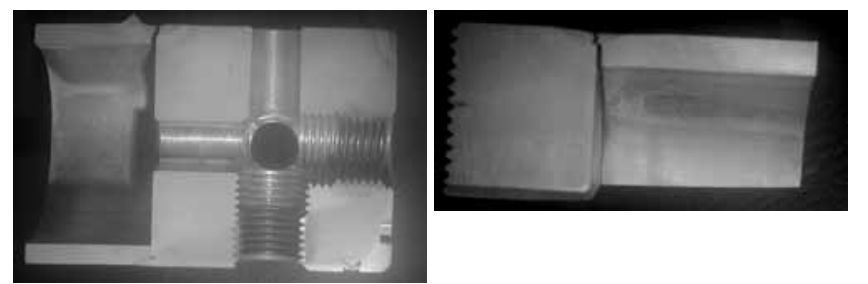

Rys. 11. Powierzchnie zgładów na przekrojach poprzecznych węzła U góry przekrojów widoczne pęknięcia spoin

Fig. 11. Cross-section in the perpendicular surface of the truss joint. The cracks in the welds are in the upper side

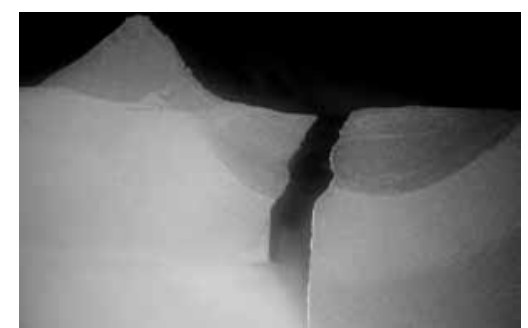

Rys. 12. Pęknięte złącze obwodowe łączące rurę z kostką węzłową. U góry po lewej stronie widoczna pozostałość spoiny po pęknięciu (odłamaniu na skutek awarii) jednej z rur węzła. Pow. 8x. Mikroskop MBS-9. Trawiono roztworem $\mathrm{NaOH}$

Fig. 12. Crack in circumferential weld between pipe and band cube. Upper left side a part of weld after crack (failure crack) in one of the pipes in the bend. Magn. 8x, MBS-9 microscope, Etching: $\mathrm{NaOH}$

\section{Badania makroskopowe}

Do badań makroskopowych wg wymagań PN-EN 1321 pobrano jeden węzeł oznaczony AGTL [łącznik przedni $(A)$, pas górny $(G)$, ściana tylna $(T)$, strona lewa (L)], który przecięto przez środek w trzech płaszczyznach prostopadle do spoin obwodowych (rys. 10). $\mathrm{Na}$ przekrojach poprzecznych wykonano zgłady metalograficzne, które po wytrawieniu roztworem $\mathrm{NaOH}$ poddano obserwacji przy użyciu mikroskopu stereoskopowego. Przykłady budowy makroskopowej złączy spawanych przedstawiono na rysunkach $11 \div 17$.

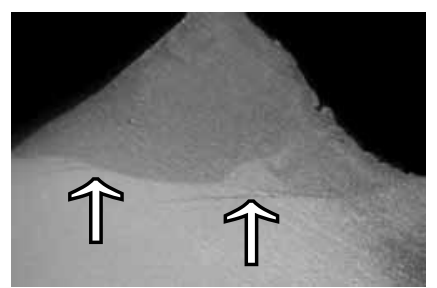

Rys. 13. Szczegół z rys. 17. Strzałki wskazują pęknięcia lamelarne w materiale rury widoczne pod linią wtopienia. Na powierzchni zgładu widoczne drobne pęcherze. Pow. 25x. Mikroskop MBS-9. Trawiono roztworem $\mathrm{NaOH}$

Fig. 13. Detail from Fig. 17. Arrows show the lamellar crack in the pipe metal below fusion line. In the cross-section surface small gas cavities. Magn. 25x, MBS-9 microscope, Etching: $\mathrm{NaOH}$

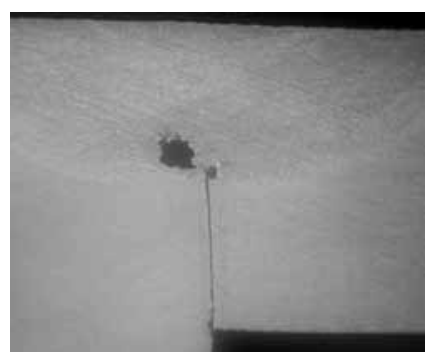

Rys. 14. Makrostruktura złącza rury z kostką węzłową. Przetop sięgający poniżej połowy grubości ścianki rury. Pęcherz gazowy i porowatość w strefie graniowej spoiny. Widoczna nieciągłość pomiędzy pęcherzem a porowatością. Pow. 20x. Mikroskop MBS-9. Trawiono roztworem $\mathrm{NaOH}$

Fig. 14. Macrostructure of pipe and bend cube joint. Penetration below the half of the pipe wall thickness. Gas cavity and porosity in the root of weld zone. Discontinuity between the gas cavity and porosity. Magn. 20x, MBS-9 microscope, Etching: $\mathrm{NaOH}$

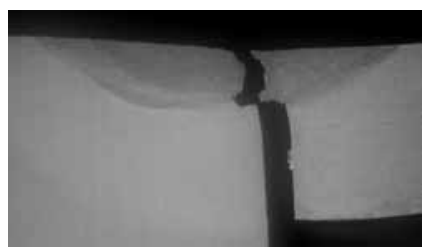

Rys. 15. Makrostruktura pękniętego złącza rury z kostką. Przetop sięgający ok. $30 \%$ grubości ścianki rury. W początkowej fazie pękanie przebiegało od braku przetopu po linii wtopienia, a następnie przez spoinę w miejscach o obniżonej wytrzymałości. Pow. 10x., Mikroskop MBS-9, Trawiono roztworem $\mathrm{NaOH}$

Fig. 15. Macrostructure of crack joints of pipe and the bend cube. Weld penetration up to $30 \%$ of pipe wall thickness. The beginning from the lack of penetration, through the fusion line, and then weld in the zone with lower strength. Magn. 20x, MBS-9 microscope, Etching: $\mathrm{NaOH}$ 


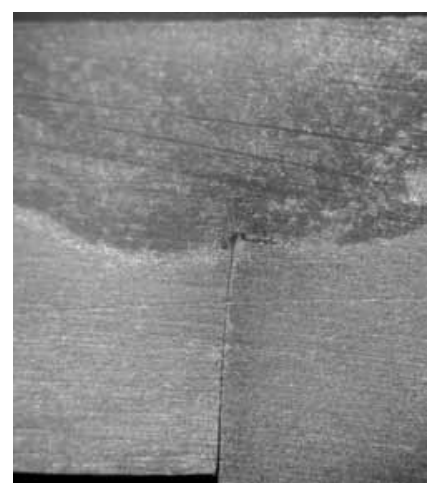

Rys. 16. Makrostruktura złącza rury z kostką. Przetop sięgający połowy grubości ścianki rury. Widoczne pęknięcie od braku przetopu w prawo od linii wtopienia. Pow. 25x. Trawiono roztworem $\mathrm{NaOH}$

Fig. 16. Macrostructure of pipe and bend cube joint. Weld penetration up to half of the pipe wall thickness. Crack beginning and propagation through the right side of fusion line. Magn. 25x, Etching: $\mathrm{NaOH}$

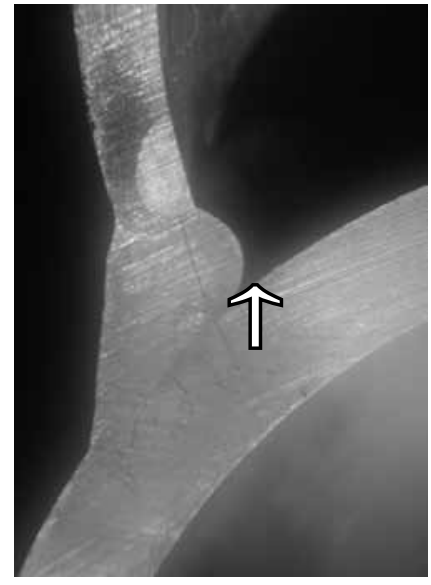

Rys. 17. Przykład przekroju spoiny krzyżulca. Pow. $5 x$. Widoczny ostry karb od strony grani

Fig. 17. Exemplary cross-section of cross brace. The shark notch on the root side. Magn. $5 x$

Z wyglądu złącza przedstawionego na rysunkach 14 i 16 można wywnioskować, że grań spoiny nie była chroniona osłoną gazu obojętnego, co spowodowało kontakt tlenu z granią. Widoczne są pęcherze gazowe oraz przyklejenia spowodowane powstaniem wysokotopliwych tlenków. Na rysunku 17 przedstawiono przekrój przez złącze obwodowe krzyżulca. Grubość spoiny odpowiada grubości ścianki rury, tj. $3 \mathrm{~mm}$, a kształt grani stanowi karb geometryczny.

\section{Ocena jakości spoin}

Brak dokumentacji technicznej dotyczącej wykonania złączy spawanych uniemożliwia dokonanie klasyfikacji jakości $z$ uwagi na brak wymagań określonych przez projektanta konstrukcji. Ze względu na charakter konstrukcji przewidzianej dla imprez masowych autorzy zakładają poziom jakości B wg PN-EN 30042 z dopuszczeniem niezgodności 502 (nadmierny nadlew lica) na poziomie C. Z analizy wizualnej wynika, że spoiny łączników narożnych wykonywane były ręcznie najprawdopodobniej metodą MIG (131) lub TIG (141) w pozycjach przymusowych, tj. bez obrotu elementów łaczonych. Badania wizualne spoin prowadzone zgodnie z wymogami PN-EN ISO 970 oraz badania makroskopowe przekrojów spoin wg PN-EN 1321 pozwoliły ujawnić (poza pęknięciami wywołanymi awarią) niezgodności spawalnicze takie jak:

- niepełny przetop (402) - wady długie w każdym pękniętym złączu,

- przyklejenie brzegowe (401 - wada długa), w szczególności od strony kostek węzłowych,

- pory gazowe (2017),

- nierówności lica (514),

- jamy skurczowe (202),

- wtrącenia tlenków (303),

- kratery w miejscu zakończenia spawania (2024).

Cyfrowe oznaczenie niezgodności spawalniczych jest zgodne z PN-ISO 6520-1 i PN-EN 30042. Zastosowany sposób przygotowania do spawania (brak ukosowania ścianek rur oraz brak odstępu pomiędzy czołem rury a kostką) nie pozwolił na uzyskanie spoin z pełnym przetopem. Głębokość wtopienia w ściankę rur, z których wykonano łączniki, wynosi ok. $2,5 \mathrm{~mm}$ przy całkowitym braku wtopienia na długości $20 \div 30 \%$ każdego obwodu (strefy z rys. 8). Kształt grani spoiny krzyżulca można uznać za niezgodność typu niewłaściwy brzeg i wskazać jako jedno ze źródeł powstania pęknięć (karb).

\section{Analiza przyczyn zniszczenia i zalecane rozwiązanie problemu}

Rozwiązanie konstrukcyjne występujące w łącznikach blokowych zakłada łączenie rur o średnicy $60 \mathrm{~mm}$ i ściance grubości $5 \mathrm{~mm}$ spoinami z monolitową kostką węzłową $60 \times 60 \times 60 \mathrm{~mm}$. Krawędź rury nie jest ukosowana, natomiast kostka ma ścięte narożniki co stwarza na części obwodu złącza warunki dla lepszego wtopienia. Głębokość maksymalna, na którą udało się wtopić spawaczowi, to ok. połowa grubości ścianki rury (tj. ok. $2,5 \mathrm{~mm}$ ) w strefie narożników kostki i na bokach zewnętrznych. Prawidłowego wtopienia w rurę na płaszczyźnie boków wewnętrznych łączników nie stwierdzono. Spoiny zewnętrzne od strony boków zostały dodatkowo pocienione przez szlifowanie nadlewu lica wystającego ponad powierzchnię kostki. Grubość spoiny, jaka pozostała na powierzchniach bocznych, zewnętrznych kostki to ok. $2 \mathrm{~mm}$.

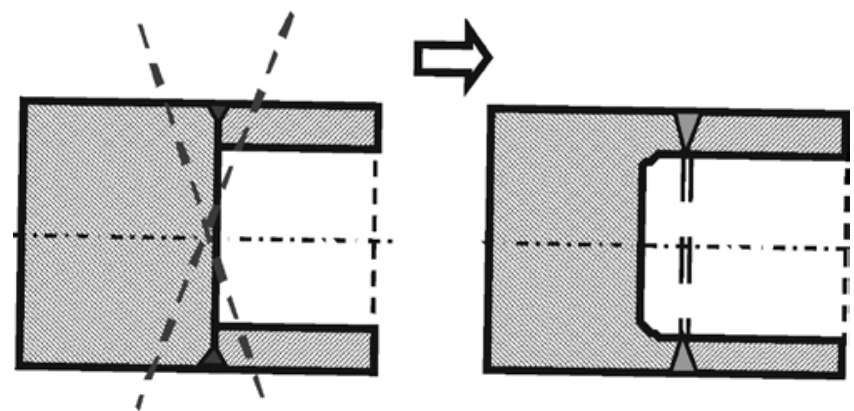

Rys. 18. Zalecana zmiana rozwiązania technologiczno-konstrukcyjnego złączy

Fig. 18. Recommend producibility-structural change for joints 
Brak przetopu w grani spoiny oraz przyklejenia spoiny do powierzchni kostki stanowią karb wewnętrzny będący powodem znacznego spiętrzenia naprężeń. Obecność takiego karbu jest również powodem wystąpienia pękania kruchego w przypadku przekroczenia naprężeń dopuszczalnych, a równocześnie sprzyja rozwijaniu się pękania zmęczeniowego. Na powierzchni przełomów nie stwierdzono wygładzonego ziarna, co mogłoby wskazywać na obecność pęknięć w konstrukcji w okresie poprzedzającym awarię, lecz nie wyklucza się powstania częściowych pęknięć na krótko przed zniszczeniem łączników konstrukcji kratowej zadaszenia. Celem wyeliminowania pęknięć w podobnych konstrukcjach autorzy zalecają zmienić stosowane rozwiązanie na poprawne pod kątem technologiczności konstrukcji - wg rys. 18 .

\section{Wnioski}

Awaria aluminiowej konstrukcji spawanej zadaszenia amfiteatru spowodowana została zastosowaniem zarówno błędnego rozwiązania technologicznego jak i konstrukcyjnego. Grań spoiny nie była chroniona gazem obojętnym.

Zastosowano niedopuszczalne z punktu widzenia technologiczności konstrukcji połączenie ścianki

rury z kostką - brak odstępu i ukosowania oraz zbyt duża różnica grubości łączonych elementów.

Kształt grani spoin krzyżulca wygenerował karb.

Zmiana konstrukcji złączy wg proponowanego rozwiązania pozwoli na wyeliminowanie ich awarii.

\section{Literatura}

[1] Hulimka J., Skwarek M., Dyrek M.: Błędy w projektowaniu, wykonawstwie i utrzymaniu wieży telekomunikacyjnej o wysokości $50 \mathrm{~m}$. XXIII Konferencja Naukowo-Techniczna „Awarie budowlane 2007". Szczecin-Międzyzdroje, maj 2007, s. 585-592.

[2] Jurczak W.: Wpływ składu chemicznego spoiw na elektrochemiczne pękanie pod naprężeniem złączy spawanych stopu AlZn5Mg2CrZr. Zeszyty Naukowe Akademii Marynarki Wojennej $n r$ 2/2007 r.

[3] Lobanow L.M.: Current directions of research work conducted in the E.O. Paton Institute of Electric Welding in the field of welding technique and welded constructions strength Biuletyn Instytutu Spawalnictwa w Gliwicach. R. 43, nr 5, s. $17-19,1999$.

[4] Robakowski T.: Wpływ wad w złączach spawanych na własności eksploatacyjne konstrukcji spawanych. Wydawnictwo Instytutu Spawalnictwa. Gliwice, 1997.

[5] Senkara J.: Czy złącze musi być najsłabszym miejscem konstrukcji. Biuletyn Instytutu Spawalnictwa Nr 5/2003.

[6] Skarbiński M., Skarbiński J.: Technologiczność konstrukcji maszyn. WNT Warszawa 1982.
[7] Stabryła J., Dutka K.: Failure analysis of weld constructions. Welding International Vol. 25, no. 7, July 2011, s. 517-522.

[8] PN-EN ISO 10042 - Złącza spawane łukowo $w$ aluminium i jego stopach.

[9] PN-EN ISO 15614-2:2005: Kwalifikowane technologie spawania metodą TIG (141) złącza doczołowego rur (ø50x2 mm, $ø 50 \times 4 \mathrm{~mm})$ ze stopu aluminium EN AW-6101.

[10] DIN V 4113-3 - Uprawnienia do spawania konstrukcji aluminiowych.

[11] DIN EN 13200 - Obiekty widowiskowe

[12] DIN EN ISO 3834-2 - Wymagania jakości dotyczące spawania materiałów metalowych; Część 2: Pełne wymagania jakości (Specjalistyczny system zarządzania jakością w spawalnictwie). Zakres stosowania: obiekty widowiskowe (konstrukcje aluminiowe, stojaki na urządzenia, ruchome podesty).

[13] DIN 1090 CE 1, 2, 3 - certyfikat zakładowej kontroli produkcji (FPC) nadany przez GSI SLV Hannover. Wykonywanie konstrukcji stalowych i aluminiowych: Część 3: Wymagania techniczne dotyczące konstrukcji aluminiowych.

[14] www.alspaw.com.pl 